\title{
Rostrum length, mandible serration, and food and salivary canals areas of selected species of stink bugs (Heteroptera, Pentatomidae)
}

\author{
Rogério A. Depieri \& Antônio R. Panizzi²
}

'Programa de Pós-Graduação em Ciências Biológicas, Entomologia, Universidade Federal do Paraná, Caixa Postal 19020, 81531-990 Curitiba-PR, Brazil. radepieri@gmail.com

${ }^{2}$ Laboratório de Bioecologia de Percevejos, Embrapa Soja, Caixa Postal 231, 86001-970 Londrina-PR, Brazil. panizzi@cnpso.embrapa.br

\begin{abstract}
Rostrum length, mandible serration, and food and salivary canals areas of selected species of stink bugs (Heteroptera, Pentatomidae). Laboratory studies were conducted to compare rostrum length morphology of mandible serration and area of food and salivary canals of Dichelops melacanthus (Dallas) (Dm), Euschistus heros (F.) (Eh), Nezara viridula (L.) (Nv), and Piezodorus guildinii (Westwood) (Pg) (Heteroptera: Pentatomidae). Nv showed the longest (5.9 mm) and Pg the shortest (3.5 mm) rostrum length; Dm and Eh were intermediate. Length and width of mandible tip areas holding serration was bigger for Nv (106.0 and 30.2 $\mu \mathrm{m}$, respectively) and smaller for $\operatorname{Pg}(71.1$ and $23.7 \mu \mathrm{m})$, with all species having four central teeth and three pairs of lateral teeth. The inner mandible surface showed squamous texture. Cross-section of food and salivary canals ( $\mathrm{Fc}$ and $\mathrm{Sc}$ ) indicated greater area for $\mathrm{Nv}$ and $\mathrm{Dm}$ compared to $\mathrm{Eh}$ and $\mathrm{Pg}$; however, the ratio $\mathrm{Fc} / \mathrm{Sc}$, yielded the highest relative area for $\mathrm{Pg}$.

KEYWORDS. Electron microscopy; mouth parts morphology; teneral adults.

RESUMO. Comprimento do rostro, dentição mandibular, e áreas dos canais alimentar e salivar de espécies selecionadas de percevejos (Heteroptera, Pentatomidae). Comparou-se em laboratório o comprimento do rostro, a morfologia da dentição mandibular e as áreas dos canais de alimento e de saliva de Dichelops melacanthus (Dallas) (Dm), Euschistus heros (F.) (Eh), Nezara viridula (L.) (Nv) e Piezodorus guildinii (Westwood) (Pg) (Heteroptera: Pentatomidae). Nv apresentou comprimento do rostro mais longo (5,9 mm) e Pg o mais curto (3,5 mm); Dm e Eh apresentaram comprimentos intermediários. O comprimento e largura da região da ponta das mandíbulas que apresentam os dentes foram maiores em Nv (106,0 e 30,2 $\mu \mathrm{m}$, respectivamente) e menores em Pg ( 71,1 e 23,7 $\mu \mathrm{m})$, com todas as espécies possuindo quatro dentes centrais e três pares de dentes laterais. A superfície interna das mandíbulas apresentou superfície com textura escamosa. Secção transversal dos canais de alimento e de saliva (Fc e Sc) indicou áreas maiores em Nv e Dm e menores em Eh e Pg; entretanto, a razão Fc/Sc, apresentou valor relativo maior para Pg.
\end{abstract}

PALAVRAS-CHAVE. Adultos teneral; microscopia eletrônica; morfologia do aparelho bucal.

Mouth parts of sucking insects (Heteroptera) show highly modified mandibles and maxillae (stylets). Different traits of the stylets including shape of the stylets tips, dentition of mandibular tips, filter hairs on maxillae, and size of food canal in several heteropterans have been studied (Faucheux 1975; Cobben 1978; Cohen 1990). In general, the stylets are hold together by a groove and ridge with interlocking "lips" that extend nearly the entire length of the stylets (Cobben 1978; Cohen 2000). In some cases, as for Oncopeltus fasciatus (Dallas) (Heteroptera, Lygaeidae), the maxillae are slightly longer than the mandibles, these ending with transverse rows of hooked teeth on the outer surface; lateral wall of the maxillae carry hooks that fit the internal grooves of mandibles, which show serrated tips, while that of maxillae are straight (Forbes 1976).

Cobben (1978) analyzed width and length of stylets, the connection between them, and the development of the salivary canal in various trophic groups. Brozek \& Herczek (2004) presented a general model of the internal structure of heteropterans mouth parts, and systematized data on the types of connection between the right and left maxillae in various groups using insects from museums. The study of external structures of heteropteran mouth parts done in insects of unknown age, either from entomological collections or from laboratory colonies (Cobben 1978; Rani \& Madhavendra 1995; Brozek \& Herczek 2004), may lead to mistakes in interpretation, due to potential mandible wear during insect aging.

Therefore, in this study we compared rostrum length, external morphology of the mandibular tip (serration), and internal areas of the food and salivary canals of four species of pentatomids, important pests of field crops in Southern Brazil, of known age that were obtained from laboratory colonies.

\section{MATERIAL AND METHODS}

Insect Colony. Adults of Dichelops melacanthus (Dallas), Euschistus heros (F.), Nezara viridula (L.), and Piezodorus guildinii (Westwood) were field-collected using a sweep net on soybean, Glycine max (L.) cultivated at the Embrapa Farm in Londrina, northern Paraná State, Brazil $\left(23^{\circ} 11^{\prime} S\right.$; $\left.51^{\circ} 11^{\prime} \mathrm{W}\right)$. They were taken to the laboratory and pairs ( $\mathrm{n}=$ $30)$ were placed in clear plastic boxes $(25 \times 20 \times 20 \mathrm{~cm})$, and provided with pods of green beans, Phaseolus vulgaris L., raw shelled peanuts, Arachis hypoagea L., and berries of privet, Ligustrum lucidum Ait. (Oleaceae). Boxes were kept in a walk-in chamber at $25 \pm 1{ }^{\circ} \mathrm{C}$ temperature, $65 \pm 5 \% \mathrm{RH}$ 
and a photoperiod of 14:10h (L:D). Food was replaced every other day and nymphs obtained were raised to adults.

Sample Preparation for Rostrum and Mandible Tip Analysis. Less than one day-old female adults $(n=10$ for each species) were selected, killed by freezing, and the rostrum length measured in a stereomicroscope Leica MZ6 (Wetzlar, Germany) with a scaled ocular. Their mandibles $(D$. melacanthus, $\mathrm{n}=8$, E. heros, $\mathrm{n}=6, N$. viridula, $\mathrm{n}=4$, and $P$. guildinii, $\mathrm{n}=4$ ) were fixed by overnight immersion into a mix of EM grade glutaraldehyde $2.5 \%$, paraformoldehyde $2 \%$, and $0.2 \mathrm{M}$ sodium phosphate $\mathrm{pH} 7.2$ buffer. The samples were rinsed with sodium phosphate buffer three times, for a total period of 45 minutes to remove the fixatives residues. Post-fixation was made on $1 \%$ sodium phosphate-buffered osmium tetroxide for one hour.

After dehydration in a series of ethyl alcohol increased concentrations, the samples were glued on carbon tape stick on specimen stub. The dried samples were gold coated with a sputter coater (BAL-TEC SCD050 ${ }^{\circledR}$, Balzers, Liechtenstein), examined and photographed in a scanning electron microscope (FEI Quanta $200^{\circledR}$, Eindhoven, Netherlands).

The mandible tip length was determined by the measurement from the $1^{\text {st }}$ tooth to the end of the $3^{\text {rd }}$ lateral teeth (Fig. 1, line a). The mandible tip width was determined by measurements taken in the middle portion of the $3^{\text {rd }}$ lateral teeth (Fig. 1, line b).

Cross-Section Areas of Food and Salivary Canals and Maxillary Stylets Junction. Because of structural irregularities in stylet apices, only sections made proximal to the bundle apex can be compared (Cobben 1978). The third rostral segment is usually well-developed, and its cross section allows better analysis of the internal connections between elements of the mouthparts, the position of the food and salivary canals, and the position of mandibles (Brozek \& Herczek 2004). Because the internal structure of the labium is irregular, it is essential that comparison of the same structural elements should be done at the same point of cross-section (Forbes 1976).

Recently molted adult females were dissected with mouthparts separated (D. melacanthus, $\mathrm{n}=20 ;$ E. heros, $\mathrm{n}=$ 20; N. viridula, $\mathrm{n}=21$; and P. guildinii, $\mathrm{n}=18$ ) and fixed by immersion overnight into a mix of EM grade glutaraldehyde $3 \%$, paraformoldehyde $2 \%$, and sodium cacodylate buffer $(0.2 \mathrm{M}, \mathrm{pH} 7.2)$ in aqueous solution. The samples were rinsed with $0.1 \mathrm{M}$ sodium cacodylate buffer three times for $15 \mathrm{~min}$ to remove all residual fixatives. Post-fixation was made on $1 \%$ cacodylate-buffered osmium tetroxide. The insect heads were dehydrated in solution with increasing concentration of ethyl alcohol, diaphanized in EM grade propylene oxide (1,2-epoxy propane), and gradually infiltrated during 5 days with mixtures of Araldite $502^{\circledR}$ epoxy resin (Hatfield, PA) and propylene oxide followed by polymerization at $60^{\circ} \mathrm{C}$ during $24 \mathrm{~h}$ in silicone flat embedding block mold.

The specimens' blocks were razor blade trimmed, and the $3^{\text {rd }}$ labium segment was cross-sectioned $(2 \mu \mathrm{m})$ with $45^{\circ}$ glass knife on ultramicrotome Leica Ultracut $\mathrm{UCT}^{\circledR}$ (Wetzlar, Germany). The sections were stained by toluidine blue on histological glass slides and mounted on Entellan ${ }^{\circledR}$ adhesive (Hatfield, PA), for light microscopy observation and photography on Zeiss Axio Imager $A 1^{\circledR}$ (Jena, Germany). The food and salivary canals areas were measured on Zeiss AxioVision ${ }^{\circledR}$ digital imaging processing software (Munich, Germany). The measured areas were used to calculate the ratio food/salivary canals $(\mathrm{Fc} / \mathrm{Sc})$, to compare the relative size of both canals of the different species.

The third labium segment were sliced $(70 \mathrm{~nm})$ on $45^{\circ}$ diamond knife (Diatome AG, Biel, Switzerland) on Leica Ultracut $\mathrm{UCT}^{\circledR}$ (Wetzlar, Germany), and supported on 200 mesh cooper grids, for observation and photography of maxillary stylets junctions, on FEI Tecnai $\mathrm{T} 12^{\circledR}$ (Eindhoven, Netherlands) electron transmission microscope. The description of the mouthparts internal structures was based on Brozek \& Herczek (2004).

Statistics. The experimental design for all trials was completely randomized. The data were submitted to ANOVA and the mean values were compared using the Tukey test $(\mathrm{P} \leq$ 0.05) (SAS Institute 1998).

\section{RESULTS AND DISCUSSION}

Rostrum and Mandible Tip Analysis. The rostrum length was variable among the different species of pentatomids examined, with $N$. viridula $(\mathrm{Nv})$ showing the longest (5.9 $\mathrm{mm})$ and $P$. guildinii $(\mathrm{Pg})$ the shortest $(3.5 \mathrm{~mm})$ values; for $D$. melacanthus $(\mathrm{Dm})$ and E. heros $(\mathrm{Eh})$ these values were intermediate and similar (Table I). In this case, rostrum length is clearly related to body length, which is known to be bigger for Nv and smaller for Pg (Panizzi \& Machado-Neto 1992). These authors reported greater values for the rostrum length of females of Nv, Eh, and Pg, which were field-collected in the same area of Brazil than the ones reported here. For the cosmopolitan Nv, Follett et al. (2009) found the mean rostrum length of $6.5 \mathrm{~mm}$ (range 5.4 to 7.5 ) for adults (most

Table I. Mean ( \pm SEM) rostrum length, mandible tip length and width, and number of teeth of teneral $(<1$ day-old) adult females of selected species of pentatomids (number of observations in parentheses).

\begin{tabular}{|c|c|c|c|c|c|}
\hline Species & $\begin{array}{l}\text { Rostrum } \\
\text { length } \\
(\mathrm{mm})^{1}\end{array}$ & $\begin{array}{c}\text { Mandible tip } \\
\text { length } \\
(\mu \mathrm{m})^{1}\end{array}$ & $\begin{array}{l}\text { Mandible } \\
\text { tip width } \\
(\mu \mathrm{m})^{1}\end{array}$ & $\begin{array}{c}\text { \# } \\
\text { Central } \\
\text { teeth }\end{array}$ & $\begin{array}{c}\# \\
\text { Lateral } \\
\text { teeth } \\
\text { pair }\end{array}$ \\
\hline $\begin{array}{c}\text { Dichelops } \\
\text { melacanthus }\end{array}$ & $\begin{array}{c}4.9 \pm 0.029 \\
b(10)\end{array}$ & $\begin{array}{c}81.0 \pm 0.75 \\
c(8)\end{array}$ & $\begin{array}{c}26.8 \pm 0.35 \\
b(8)\end{array}$ & 4 & 3 \\
\hline $\begin{array}{l}\text { Euschistus } \\
\text { heros }\end{array}$ & $\begin{array}{c}5.1 \pm 0.030 \\
\mathrm{~b}(10)\end{array}$ & $\begin{array}{c}87.9 \pm 0.89 \\
b(6)\end{array}$ & $\begin{array}{c}27.0 \pm 0.36 \\
b(6)\end{array}$ & 4 & 3 \\
\hline $\begin{array}{l}\text { Nezara } \\
\text { viridula }\end{array}$ & $\begin{array}{c}5.9 \pm 0.046 \\
\text { a (10) }\end{array}$ & $\begin{array}{c}6106.0 \pm 1.11 \\
a(4)\end{array}$ & $\begin{array}{c}30.2 \pm 0.50 \\
\mathrm{a}(4)\end{array}$ & 4 & 3 \\
\hline $\begin{array}{l}\text { Piezodorus } \\
\text { guildinii }\end{array}$ & $\begin{array}{c}3.5 \pm 0.094 \\
\text { c (10) }\end{array}$ & $\begin{array}{c}71.1 \pm 1.08 \\
\mathrm{~d}(4)\end{array}$ & $\begin{array}{c}23.7 \pm 0.43 \\
\mathrm{c}(4)\end{array}$ & 4 & 3 \\
\hline
\end{tabular}

${ }^{1}$ Means followed by the same letter in each column do not differ significantly using the Tukey test $(\mathrm{P} \leq 0.05)$. 


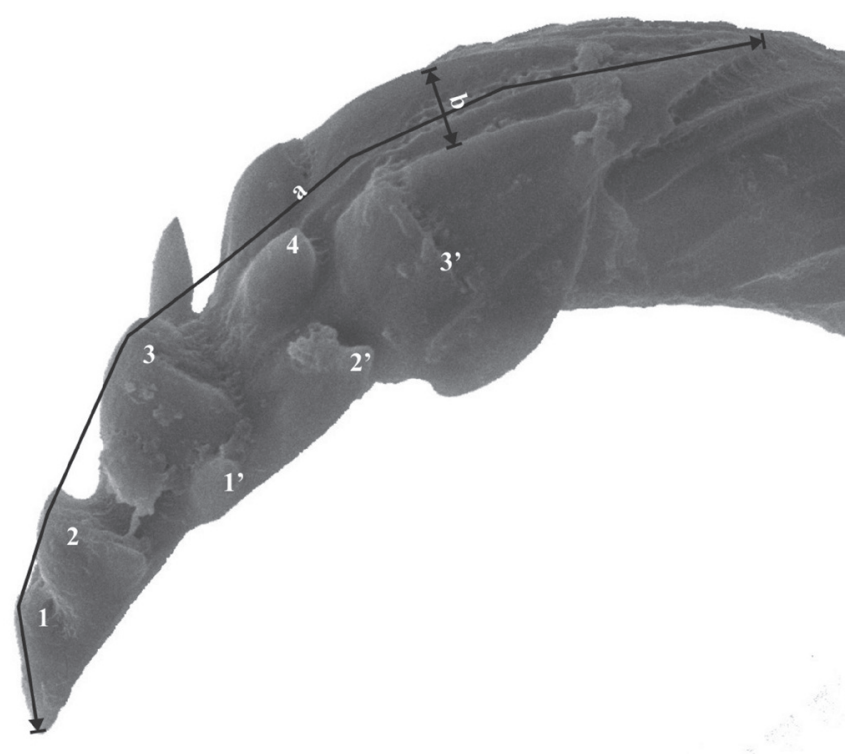

Fig. 1. Scanning electron microscopy of the mandible tip of an adult pentatomid showing how mandible measurements were taken. Mandible tip length (line a); mandible tip width (line b). Numbers 1-4 indicate central teeth; 1'-3' indicate lateral teeth (augmentation 1,200X).

probably a mixture of males and females), which were fieldcollected in Hawaii, also greater than the values we report. Although we did not measure body length of females used, our laboratory $\mathrm{Nv}$ specimens examined were certainly smaller than the ones reported in the two studies referred, since in these studies they were obtained in nature; usually lab specimens of pentatomids are smaller than field-collected ones (A.R. Panizzi, unpublished).

The length and width values of mandible tips (areas holding serration) was also bigger for $N$. viridula and smaller for $P$. guildinii (Table I). E. heros showed mandible tip length greater than $D$. melacanthus, but mandible tip width was similar (Figs. 1 and 2). Cohen (1990) observed mandible teeth ranging from 16 to 17 in reduviids down to few in pentatomids and lygaeids. The mandible tips in D. melacanthus and in $P$. guildinii were similar in border shape, and lack the squamous texture structures observed for E. heros and $N$. viridula (Fig. 2 A-D). The inner surface of the mandible of the four species has squamous texture. This groove accommodates the longitudinal external maxillary rib. Cobben (1978) refers that the orientation of this pavement is such that the forward thrust of one mandible will cause considerable friction against the outer surface of the adjacent maxillary stylet contributing to its inward deviation.

The selection of adults of known age to study the mandible dentation and rostrum length is because wear of the tip of the mandibular stylet as a result of aging and feeding on different food sources has been documented in Heteroptera. Roitberg et al. (2005) working with the zoophytophagous mirid Dicyphus hesperus Knight found that older females had greater mandibular teeth wear than younger ones. Moreover, they reported that mandible stylets wear was increased when bugs feed on plants, compared to those offered water only; this wear is caused by the resistance of tissue penetration imposed to the stylets. In a similar way, Depieri et al. (in press) found significant wear of the mandibular tip of the pentatomid Euschistus heros (F.) for old adults that were fed hard foods to penetrate, compared to younger (teneral) adults that did not have any feeding experience. Therefore, choosing bugs of known age is a critical issue in this type of study.

Cross-Section Areas of Food and Salivary Canals and Maxillary Stylets Junction. The cross-section area of the food canal $(\mathrm{Fc})$ and the salivary canal $(\mathrm{Sc})$ on the third rostral segment showed higher values for $N$. viridula and $D$. melacanthus compared to E. heros and P. guildinii (Table II). The latter showed the smallest food and salivary canals areas. These results are probably related to body size, i.e., the greater the body size, the larger the area of the cross section of the canals. However, when considering the ratio $\mathrm{Fc} / \mathrm{Sc}, P$. guildinii showed the highest relative value, which indicates a relatively larger food canal. This species is known to be the most damaging pentatomid species on soybean, Glycine max (L.), seeds (Sosa-Gómez \& Moscardi 1995; Corrêa-Ferreira $\&$ Azevedo 2002), but the reason for that was unknown. Recently, it was demonstrated that the greater seed area destroyed by $P$. guildinii compared to other pentatomids is due to the greater action of the saliva on the seed cells tissues (Depieri \& Panizzi in press). The ecological significance of the relatively bigger canal on this last species considering the ratio $\mathrm{Fc} / \mathrm{Sc}$ has not been proved. Clearly, additional studies are needed to fully demonstrate if this larger ratio value can be related to greater feeding damage or food consumption.

In conclusion, these results indicate that these species of pentatomid pests have variable rostrum length, and variable morphology of mandible serration and area of food and salivary canals. These features, including those related to mandible dentation and canal areas that were characterized for the first time in these species, may help to better understand the extent of damage they cause when feeding on seeds and/ or vegetative tissues of their host plants.

Table II. Mean ( \pm SEM) area of cross-section of food and salivary canals, and food/salivary canals ratio $(\mathrm{Fc} / \mathrm{Sc})$ on the $3^{\text {rd }}$ rostral segment of selected species of pentatomids (number of observations in parentheses).

\begin{tabular}{|c|c|c|c|}
\hline Species & $\begin{array}{c}\text { Food canal } \\
\text { area } \\
\left(\mu \mathrm{m}^{2}\right)^{1}\end{array}$ & $\begin{array}{c}\text { Salivary canal } \\
\text { area } \\
\left(\mu \mathrm{m}^{2}\right)^{1}\end{array}$ & $\mathrm{Fc} / \mathrm{Sc}^{1}$ \\
\hline $\begin{array}{c}\text { Dichelops } \\
\text { melacanthus }\end{array}$ & $\begin{array}{c}144.1 \pm 4.72 \mathrm{a} \\
(20)\end{array}$ & $\begin{array}{c}98.3 \pm 3.39 \mathrm{ab} \\
(20)\end{array}$ & $\begin{array}{c}1.48 \pm 0.05 \mathrm{ab} \\
(20)\end{array}$ \\
\hline $\begin{array}{l}\text { Euschistus } \\
\quad \text { heros }\end{array}$ & $\begin{array}{c}120.8 \pm 2.81 b \\
(20)\end{array}$ & $\begin{array}{c}87.6 \pm 2.79 b \\
(20)\end{array}$ & $\begin{array}{c}1.39 \pm 0.03 b \\
(20)\end{array}$ \\
\hline $\begin{array}{l}\text { Nezara } \\
\text { viridula }\end{array}$ & $\begin{array}{c}159.6 \pm 5.10 \mathrm{a} \\
(21)\end{array}$ & $\begin{array}{c}104.1 \pm 3.55 \mathrm{a} \\
(21)\end{array}$ & $\begin{array}{c}1.55 \pm 0.5 \mathrm{ab} \\
(21)\end{array}$ \\
\hline $\begin{array}{l}\text { Piezodorus } \\
\text { guildinii }\end{array}$ & $\begin{array}{c}97.6 \pm 3.15 c \\
(17)\end{array}$ & $\begin{array}{c}62.1 \pm 1.88 \mathrm{c} \\
(17)\end{array}$ & $\begin{array}{c}1.59 \pm 0.07 \mathrm{a} \\
(17)\end{array}$ \\
\hline
\end{tabular}

${ }^{1}$ Means followed by the same letter in each column do not differ significantly using the Tukey test $(\mathrm{P} \leq 0.05)$. 

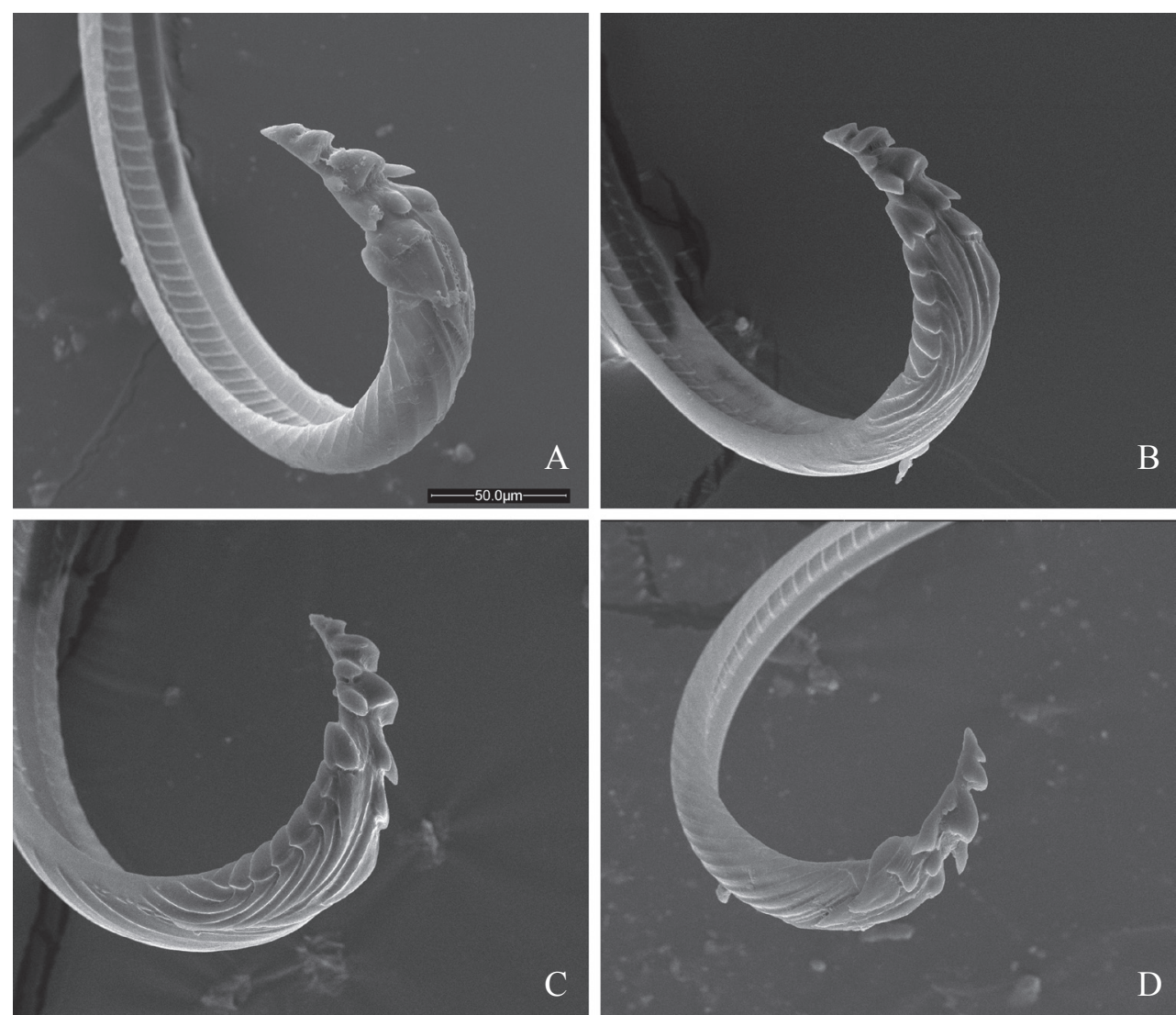

Fig. 2. Scanning electron microscopy of mandibular stylets of pentatomids. $\mathrm{A}=$ Dichelops melacanthus, $\mathrm{B}=$ Euschistus heros, $\mathrm{C}=$, Nezara viridula and $\mathrm{D}$ = Piezodorus guildinii (augmentation 600X).

Acknowledgments. We thank Norman Neumaier and Daniel R. SosaGómez for critically reading the manuscript and Simone S. Prado for assistance. This research was supported by a scholarship to RAD from the National Research Council for Scientific and Technological Development (CNPq), and through laboratory facilities provided by the Embrapa National Soybean Research Center and Paraná State University at Londrina, PR, Brazil. This paper was approved for publication by the Editorial Board of Embrapa Soja as manuscript number 22/2009.

\section{REFERENCES}

Brozek, J. \& A. Herczek. 2004. Internal structure of the mouthparts of true bugs (Hemiptera: Heteroptera). Polish Journal of Entomology 73: 70-106.

Cobben, R. H. 1978. Evolutionary trends in Heteroptera Part II: Mouthpart-structures and feeding strategies. Wageningen, Mededelingen Landbouwhogeschool 78-5. H. Veenman \& Zonen B.V., $\mathrm{v}+407 \mathrm{p}$.

Cohen, A. C. 1990. Feeding adaptations of some predaceous Hemiptera. Annals of the Entomological Society of America 83: 1215-1223.

Cohen, A. C. 2000. How carnivorous bugs feed, p. 563-570. In: Schaefer, C. W. \& A. R. Panizzi. (eds.). Heteroptera of Economic Importance, Boca Raton, CRC Press, $\mathrm{xx}+828 \mathrm{p}$.

Corrêa-Ferreira, B. S. \& J. Azevedo. 2002. Soybean seed damage by different species of stink bugs. Agricultural and Forest Entomology 4: $145-150$.

Depieri, R. A.; Siqueira, F. \& A. R. Panizzi. (in press). Aging and food source effects on mandibular stylets teeth wear of phytophagous stink bug (Heteroptera: Pentatomidae). Neotropical Entomology 39.

Received 1/2/2010; accepted 4/11/2010

Editor: Daniela Maeda Takiya
Depieri, R. A. \& A. R. Panizzi. (in press). Duration of feeding and superficial and in-depth damage to soybean seed by selected species of stink bugs (Heteroptera: Pentatomidae). Neotropical Entomology 40.

Faucheux, M. M. 1975. Relations entre l'ultrastructure des stylets mandibulaires et maxillaries et la prise de nourriture chez les Insectes Hemipteres. Comptes Rendus des Séances de l'Académie des Sciences. Série D, Sciences Naturelles 281: 41-44.

Follett, P. A.; Wright, M. G. \& M. Golden. 2009. Nezara viridula (Hemiptera: Pentatomidae) feeding patterns in macadamia nuts in Hawaii: nut maturity and cultivar effects. Environmental Entomology 38: 1168-1173.

Forbes, A. R. 1976. The stylets of the large milkweed bug, Oncopeltus fasciatus (Hemiptera: Lygaeidae) and their innervation. Journal of Entomological Society of British Columbia 73: 29-32.

Panizzi, A. R. \& E. Machado-Neto. 1992. Development of nymphs and feeding habits of nymphal and adult Edessa meditabunda (Heteroptera: Pentatomidae) on soybean and sunflower. Annals of the Entomological Society of America 85: 477-481.

Rani, P. U. \& S. S. Madhavendra. 1995. Morphology and distribution of antennal sense organs and diversity of mouthparts structures in Odontopus nigricornis (Stall) and Nezara viridula L. (Hemiptera). International Journal of Insect Morphology and Embryology 24: 119-132.

Roitberg, B. D.; Gillespie, D. R.; Quiring, D. M. J.; Alma, C. R.; Jenner, W. H.; Perry, J.; Peterson, J. H.; Salomon, M. \& S. VanLaerhoven. 2005. The cost of being an omnivore: mandible wear from plant feeding in a true bug. Naturwissenschaften 92: 431-434.

SAS Institute Inc. 1998. SAS user's guide: Statistics. Version 6.12. SAS Institute, Cary, v $+584 \mathrm{p}$.

Sosa-Gómez, D. R. \& F. Moscardi. 1995. Retenção foliar diferencial em soja provocada por percevejos (Heteroptera: Pentatomidae). Anais da Sociedade Entomológica do Brasil 24: 401-404. 